\title{
Et Cetera Photobooks? Reflections on Conceptual Documentary Photography as Visual Enumeration
}

\author{
Anja Schürmann
}

Photography has thus far been conceptualized not as a list but as a series. This contribution aims to question the photographic series in terms of enumerative functions and modes of representation. I will ask whether visual enumeration is a viable possibility and, if so, how. I will ask whether photography, and in this particular case the Conceptual Documentary photobook, ${ }^{1}$ is particularly suited to assign an enumerative, a "serial" function to the image and how that enumerative function is communicated to the viewer. One thesis is that the role of the viewer in the CDp is strengthened. The viewer is not "only" the recipient but active constructor of the work. We can define an enumeration as a kind of inventory or catalogue, if they represent a characteristic (like names), we can speak of a register. An archive or inventory of categories presents the user with a series of instances without a narrative thread; the book form, however,

\footnotetext{
A. Schürmann $(\bowtie)$

Institute for Advanced Study in the Humanities Essen (KWI), Essen, Germany e-mail: anja.schuermann@kwi-nrw.de

(C) The Author(s) 2022

R. A. Barton et al. (eds.), Forms of List-Making: Epistemic, Literary, and Visual Enumeration, https://doi.org/10.1007/978-3-030-76970-3_13
} 
suggests and inevitably creates a sense of progress from beginning to end. ${ }^{2}$ Yet, how are these opposing dynamics reconciled and transformed when the archive or list is reproduced in the form of a photobook? Both the book and the list satisfy a need for order, for a distinct selection. However, if the list is generated from the anthropological need to name and order unknown things, there should be no visual lists, as the act of naming is (necessarily) precluded. Images are not distinct signs. I argue that in order to become enumerative, the image must have a marked grasp on the word. To speak of visual lists is possible through the adaptation of verbal sign systems on several transmedial levels. However, the image has to undergo various operations to achieve this alignment. The image must be reduced and semantically limited in order to become a distinct and isolated item with a countable element. In order to achieve this, unifications are necessary that align the individual images with each other. To put it in a nutshell: at least to some degree, the photographic series must become a serial work.

In the following I introduce the term "et cetera photobook" in order to attribute another, more serial component to the Conceptual Documentary photobooks discussed in this chapter. As I will later explain in more detail, this term highlights the process of continuously adding new items and the aesthetics associated with this additive mode of presentation. To a certain extent, I owe this phrase to Peter Bexte. In his book Konjunktur \& Krise he examines the conjunction "and" in images and texts, not only as a linguistic phenomenon but also as a structure of thought (see Bexte 2019). With this term I want to make clear that seriality in the photobook cannot be defined only by a certain set of themes, as is the case in the documentary discourse on concepts such as power, memory, and testimony. The visual plural also functions as a formal criterion and forms its own aesthetics.

\section{From Series to Photobook, from Рhotobook to Conceptual Documentary Photobook (CDP)}

In scholarly research little has been said about the visual list. The following considerations will take up the concept of plural images as hyperimages as described by Thürlemann (2013). ${ }^{3}$ He mainly emphasizes two principles that are at work when we deal with images in the plural: first, the principle of reciprocal sharpening and, second, the principle of distancing. ${ }^{4}$ Both 
principles negotiate the connection between parts and the whole and are therefore important for any consideration of visual series (see Thürlemann $2013,16)$. A series refers to an artistic work which consists of parts that are independent but which together form a whole. A series is an umbrella term that has many manifestations. A painted medieval winged tartar can be considered a series, as can a comic strip or Upper Italian Renaissance frescoes that embellish representative villas. Another form is serial works. As a demarcation to series, serial works are characterized by a "numerical or otherwise systematically predetermined process (permutation, progression, rotation, reversal)" (Bochner 1967, 23). The sequence in turn designates the way in which those parts are arranged.

Visual series have recently been the subject of two studies that discuss the minimum number of images that can be considered a "series." The question also seems relevant for the discussion of lists. Martina Dobbe allows serial orders to begin with six or more objects, since each element then "resists separation through perception" (see Dobbe 2013, 38). Bettina Dunker later also lets her "picture plural" begin with six; she explicitly excludes diptychs and triptychs-also because of their "religious horizon(s) of meaning" (Dunker 2018, 11).

However, there is such thing as an "excess" of pictures, as Dobbe and Dunker make clear. Where "the equivalence of the individual elements is lost" (Dobbe 2013, 39), where "repetition and variation of a certain pictorial pattern" (Dunker 2018, 12) are lost in the mass, the plural overtaxes the series. Dunker concludes her considerations with the thesis that imagesets in which "the individual image $[\ldots]$, as well as the arrangement and the exact number" (Dunker 2018, 12), are interchangeable, do not represent serial concepts. ${ }^{5}$ These considerations suggest that lists and enumerations can also express and represent some kind of "information overload" rather than providing order or structure. Can lists express order and abundance at the same time? The question nicely leads us to the photobook as both a plural and a comprehensive picture compilation. In a conventionally bound book three principles of order can be distinguished: the double page, possibly chapters, and the material body of the book as a whole. Before I consider whether (and how) photography becomes enumerative in the context of the photobook, I will first present a few basic considerations about the photobook and its encounter with Documentary Conceptual Art. 


\section{The Conceptual Documentary Photobook (CDP)}

In this paragraph I would like to introduce the concept of the CDp, which was essentially coined by Melissa Miles (see Miles 2010) and transfers the approach of Conceptual Documentary Art to photography and the photobook. Since the three photobooks I will analyze all belong to this "genre" to varying degrees, I find it helpful to highlight those characteristics influenced by Miles, starting with a brief definition of the photobook. One of the most informative definitions of the photobook comes from Andrea Nelson:

Photobooks are publications characterized by the careful sequencing and editing of photographic images in order to convey visual arguments. They imply authorship by a photographer or photo-editor and are not intended to describe a book simply containing photographs nor a compendium of photographs illustrating a text. (Nelson 2007, 10)

The formulation "careful sequencing" used by Nelson does not distinguish between artists' books and books that are not produced in an artistic context. Her definition strengthens the thematic openness of the photobook. The photobooks discussed in this paper are also "photobookworks" in the sense that they interrelate "between two factors: the power of the single photograph and the effect of serial arrangements in book form" (Sweetman 1985, 187). Clive Scott states that the photobook is able "to capitalize on our natural need to read series as sequence, and sequence as consequence" (Scott 1999, 215). The photobook of Conceptual Documentary photography deliberately frustrates the expectation of "consequence." Conceptual Documentary photobooks do not create a narrative with a beginning, climax, and end. Melissa Miles explains that

Conceptual Documentary photography is characterized by a desire to explore a single, often banal idea from many different angles [...]. Rather than submerging themselves in dramatic events, Conceptual Documentary photographers seek out and frame their subjects according to a predetermined idea or scheme. Processes of repetition and categorization are central to Conceptual Documentary. (Miles 2010, 50)

As we see, the concept has set out to respond to the criticism against humanist photography ${ }^{6}$ by combining the tradition of humanist photography with ideas of seriality and Conceptual Art. The humanist-or 
"concerned"-photographer is someone who not only thinks and sees through his camera but also decidedly "feels" and thereby hopes to transport that feeling into the photographs. He thus abandons the objectivity usually typical for documentary art as he concentrates on his subjective feelings, often assuming that objectivity is hardly attainable in complex situations. ${ }^{7}$ Although they are often conceived with a decidedly political stance, the CDps-unlike in humanistic photography-do not show closeups of suffering victims, no photography of dismay.

Aesthetically, the CDp certainly has precursors within photobook production. In the following paragraph I introduce some of the works that are important for contextualizing the enumerative function of photography, as these can provide an idea of the historical development of the visual characteristics of the CDp. The first work I want to discuss is one of the first photobooks ever: William Henry Fox Talbots' The Pencil of Nature from 1844 .

Order and orientation were two of the most important functions with which Talbot promoted his invention of the photographic negative. According to him, a photo was a lot more efficient, faster, and precise when it came to documenting a collection of Chinese porcelain, for example, than a written inventory: "The more strange and fantastic the forms of his old teapots, the more advantage in having their pictures given instead of their descriptions". ${ }^{8}$ Carol Armstrong calls the resulting genre "inventorial photograph" (Armstrong 1998, 127). The inventorial photograph already reveals some basic visual assumptions that later become relevant for the CDp (Fig. 13.1).

The Chinese porcelain is shown in such a way that the objects maintain a constant distance not only from each other but also from the viewer. The picture ground is parallel to the picture planes and identical to the shelf wall; the oculus is in the middle of the picture; the horizontal lines run parallel with the edges. The spatial depth is minimal, the illumination uniform. For Friedrich Weltzien, these photographs are not only archival aids but at the same time function as an "Enlightenment movement of tidying up and sorting" with regard to "an ideal of clarity" and politeness, since correct distancing and appropriate spacing were becoming synonymous with civility in the Enlightenment (see Weltzien 2006, 29). The distance described (polite and respectful) is also important with regard to the CDps. In the context of CDps, the photographer is not a "concerned photographer," but someone who tries to keep and maintain distance, both toward his objects and toward the viewers and their perception. 


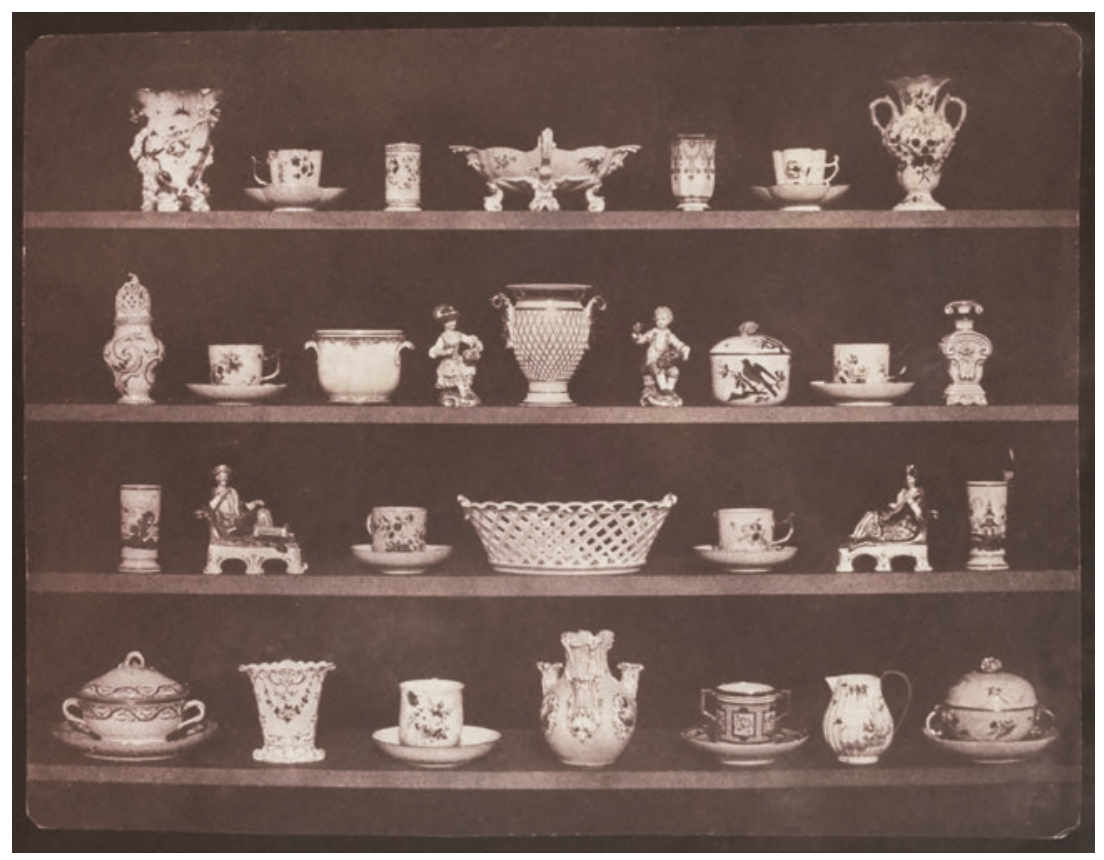

Fig. 13.1 William Henry Fox Talbot, Articles of China, 1844, Detroit Institute of Art, Creative Commons CC0 1.0 Universal Public Domain Dedication

While the origin of the visual list as we find it in the collection inventories-which are often arranged according to specific criteria-is limited to a single page, our next example, Karl Blossfeldt's photobook Urformen

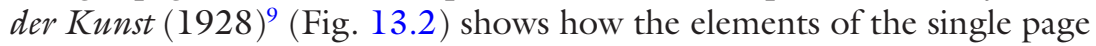
can be distributed throughout the length of a book.

Blossfeldt's plant photographs were not only botanically innovative: the isolation and sculptural arrangement of the natural objects went beyond Talbot's even spacing. For Ed Ruscha, Blossfeldt's sacrosanct “uniformly operative principle of form" (see Molderings 1977, 73)-both in nature and in technique - turns profane. ${ }^{10}$ His books have had a significant impact on the CDp: he implements the serial element of repetition in his works, 


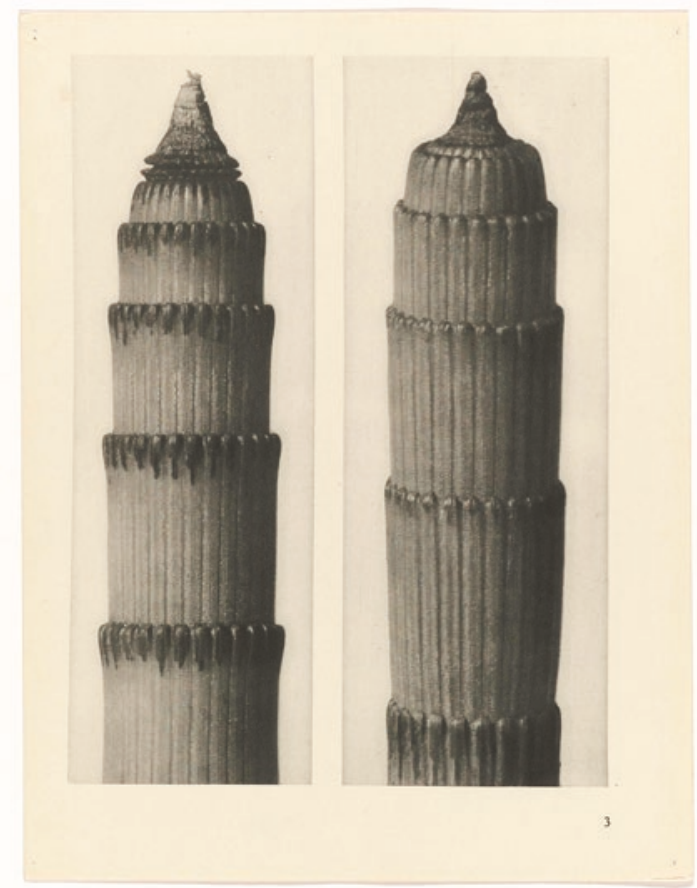

Fig. 13.2 Karl Blossfeldt, Urformen der Kunst (Berlin 1928), 3, Rijksmuseum Amsterdam, Creative Commons CC0 1.0 Universal Public Domain Dedication

be it with small fires, with petrol stations, or parking lots. Indeed, such repetition tends to reinforce the image. Its formal and aesthetic aspects are amplified, while the relevance of the depicted is diminished. ${ }^{11}$ Ute Eskildsen recently suggested that conceptual artists like Ruscha, who conceived photography as the epitome of mass media, gave new impulses to the CDp and the photobook as a high-circulation artist's book in general (see Eskildsen 2004, 27). The three photobooks presented in the following acknowledge this serial and conceptual legacy but combine it with another, namely, the political and socially critical heritage of humanist photography. 


\section{Ricardo Cases, El Porqué De Las Naranjas, MACK 2014}

On opening Ricardo Cases' photobook El porqué de las naranjas we see (next to the title) a photograph in which an orange is trapped between a curb and a car tire. This remains one of the few oranges that Cases depicts, even though the title translates as The Reason for Orange(s). Cases explains in an interview that the fruit is "one of the symbols of the Levante region," as well as of "tourism and construction" (Pantall 2014). When we turn the page, the orange fruit transforms into the color that collects as oil in the middle of a paella pan (Fig. 13.3). Later in the book the leitmotif, the color of orange, reappears in leaves that turn orange or wooden slats, plastic tarpaulins, and small or large fires (Fig. 13.4). ${ }^{12}$ Even if the color detaches itself from the object in the course of the book, as a surface color it often remains associated with the background in the picture. Cases' colors are bright and saturated because the sun plays a significant role in his portrait of the Levante region. His use of light gives the work a penetrating and relentless presence: no shadow remains unexplored, nobody

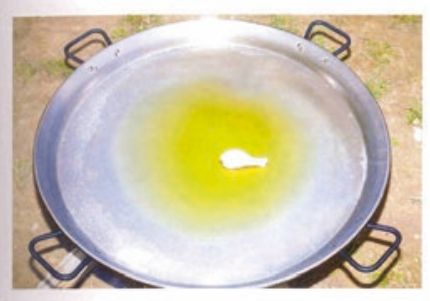

Fig. 13.3 Ricardo Cases, El porqué de las naranjas (London 2014), n.p., (C) Ricardo Cases 


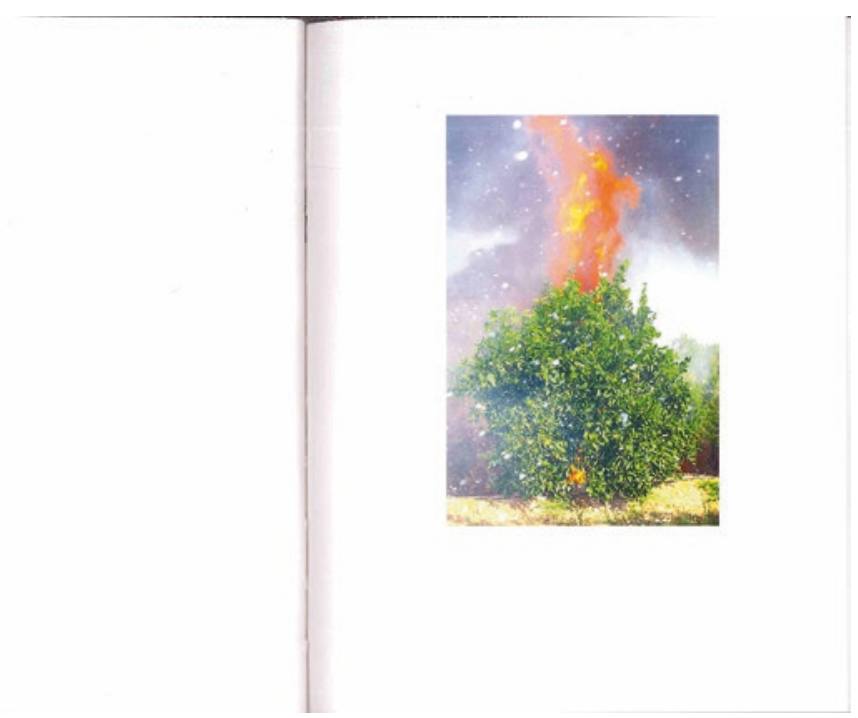

Fig. 13.4 Ricardo Cases, El porqué de las naranjas (London 2014), n.p., (C) Ricardo Cases

can hide. The sharp-edged overexposure is often aided by flashes; these give the objects a surprised, even trapped look as if they had been caught. That flashlight aesthetic resonates with the local past: the Levante has been a tourist destination, once very popular, today a victim of real estate speculators and financial crisis. The transitions of the image are often formally motivated: a round object is correlated with a likewise round object in the next picture; the exposure time has changed from one picture to the next. Although Cases, in line with the cinematic principle, only sets one image per double page, the book is primarily arranged in pairs of images, not in larger sequences. Despite the luminosity of the colors, it must be viewed from a short distance, especially since the photos are printed relatively small, which increases individual attention. In terms of reception aesthetics, the reader repeatedly tries to discover the color orange in this series of images. And the reader usually (yet not always) succeeds. This dissolves the form into abstraction while simultaneously endangering it with such clear instructions such that the search for the color is abandoned as soon as it is found. 
Due to the differentiated use of the color orange, sometimes lighter, sometimes darker, sometimes used extensively or as a small accent, the search is never easy or unconditional. In this search, the contexts of this withered and emaciated region cannot be ignored. Just as the color orange repeatedly reappears and cannot be overlooked, so, too, the economic crisis that shapes the region is omnipresent-even if only in minor and easily overseen details. ${ }^{13}$ The enumerative quality of the book is obvious. The title of the book works as a connecting hypernym, while the formally designed sequence has linearity in its compositional geometry, although it is still far from being diagrammatic.

The enumeration refers-regardless of the object-to signifiers (see Eco 2009, 118), while Allison Stewart and Stephen Gill, the authors of the photobooks introduced in the following, count the signified. This means that Cases' use of the color orange emphasizes the expressive side of the sign, whereas-as we will see in the following-Gill and Stewart tend to highlight the thematic aspects of their enumeration. Cases has pointed out several times that he wanted to start his project "openly", that he viewed the photographs as "autonomous" (Pantall 2014), an autonomy that, since the degree of staging is relatively low in Cases, remains visible - in contrast to Stewart and Gill.

\section{Allison Stewart, Bug Out Bag: The Commodification of American Fear, Self-Published 2018}

If the fairly discrete elements in Cases were arranged one behind the other on different pages, in Bug out Bag they lie next to each other on the same page. "Bug out bags" are bags that are intended as basic equipment for disaster preparedness and serve either as a 72-hour survival kit or as a means to rebuild civilization. The spiral-bound book, which also focuses on the commercialization of prepping by showing trade fairs and other places of supply for utilities, is visually reminiscent of a manual, a printed aid, or guide that provides instructions in case of emergency. As functional as this travel occasion may be, the photos by Allison Stewart show that each bag allows individual conclusions to be drawn about the character of the packer, about his idea of society and solidarity, and about order and control in situations that are hard to imagine. If one understands the list as a phenomenon of crisis (see Bexte 2014, 27), as a possibility to create order and thus assert control in a disordered world, Stewart's work is 
doubly relevant for the theme of this essay: on the representational as well as on the iconic level.

The objects in the photographs are singularized, intentionally exempted. They do not attempt to tell a story but rather stage specific isolated (and more or less deliberately constructed) scenes. Stewart uses her mobile photo studio to show the unwrapped emergency backpacks on an even white background. They are central to the content, which is arranged more or less in a row around them. In this microcosm, the objects certainly function as stimuli or references to a narrative (see Wolf 2002, 43): while Mike from Texas encounters the apocalypse with tequila and phenobarbital (Fig. 13.5), Sam's backpack reflects his need for communication by packing "walkie talkies" and a radio (Fig. 13.6).

The sparse titles assigned to the panels activate the viewer as a ( $\left.\mathrm{co}^{-}\right)$ constructor of the narrative. ${ }^{14}$ The intended viewers would complement and connect the given image with Mike's or Sam's idea of what would be important in and after the expected catastrophe. It seems that the more

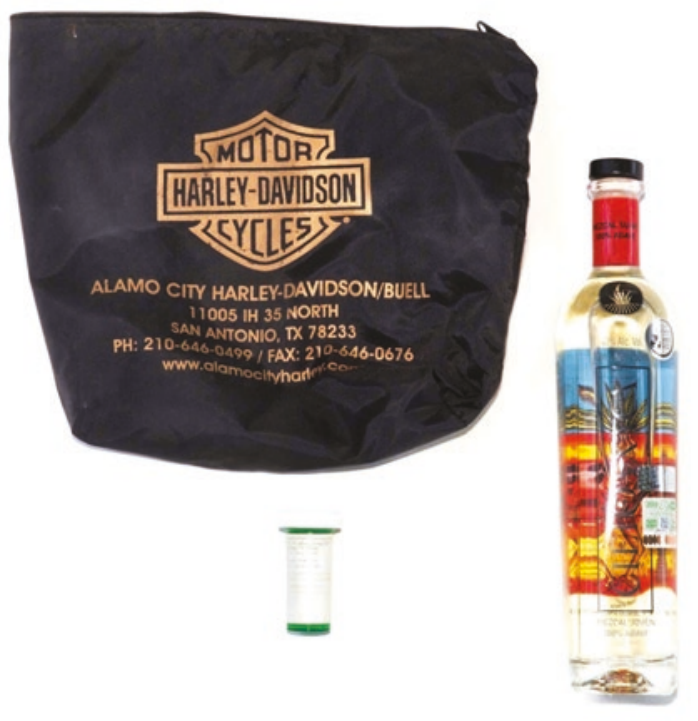

Fig. 13.5 Allison Stewart, Bug Out Bag: The Commodification of American Fear (2018), self-published, 23, @ A Allison Stewart 


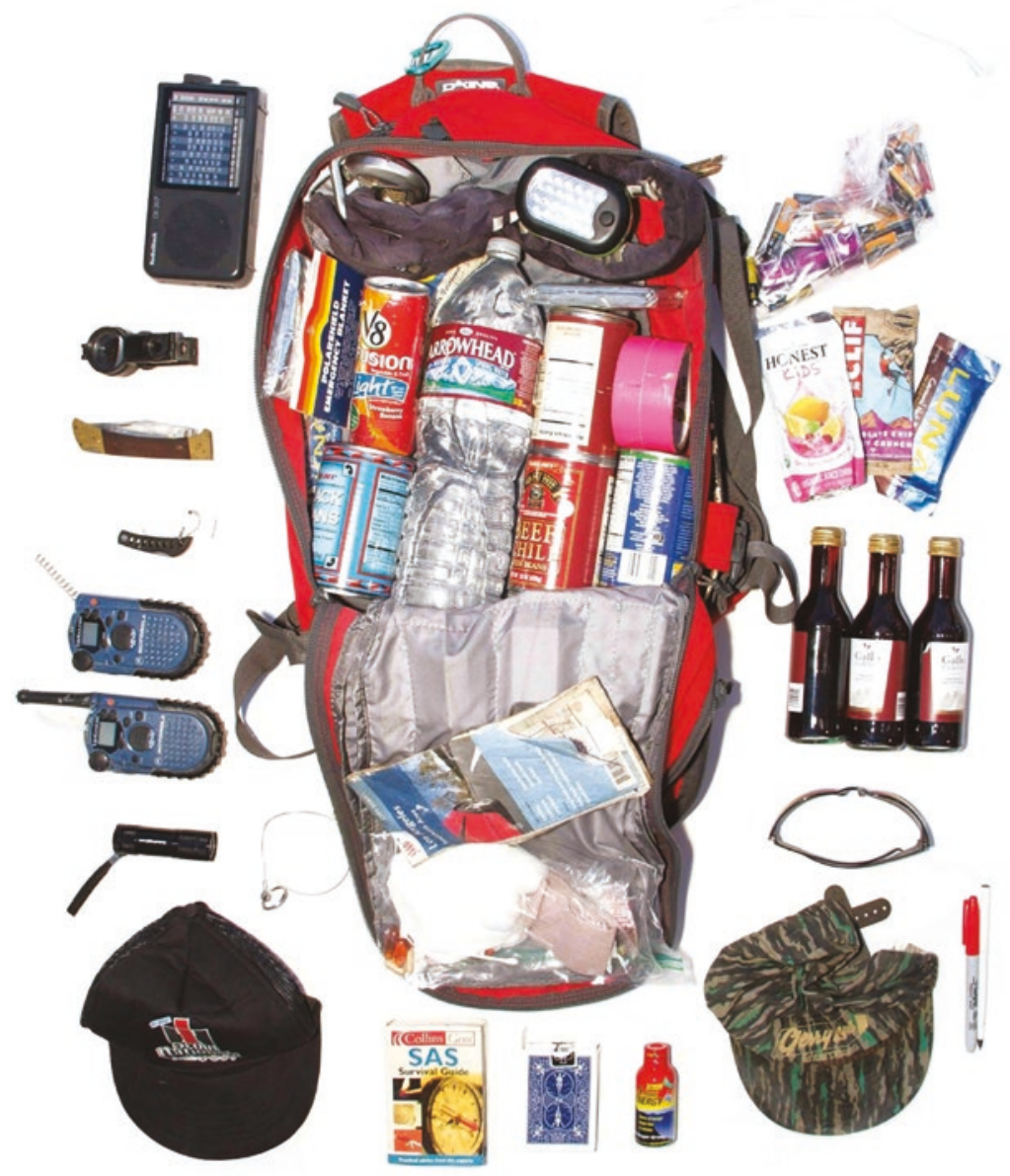

Fig. 13.6 Allison Stewart, Bug Out Bag: The Commodification of American Fear (2018), self-published, 25, (c) Allison Stewart 
sparingly explanatory elements or narrative stimuli are used, the more active the viewer has to be. Although Stewart, like Talbot in his inventory (Fig. 13.1), combines the objects in one image, the oversight and inequality of the objects create a different effect: due to the singularizing type of recording and the neutral perspective afforded by the overhead perspective, the objects become findings or clues in a crime scene that not only function prospectively but also retrospectively. The objects depicted could be instructions but also the legacies of their owners, posthumous testimonies after the catastrophe. A similar representation where the photos qualify as found objects can also be observed in the photobook by Stephen Gill, in which people are identified by what they leave behind.

\section{Stephen Gill, a Series of Disappointments, Nobody 2008}

The pages in Stephen Gill's A Series of Disappointments are heavy and slightly larger than a usual piece of paper. Also photographed from above, they display differentially illuminated objects on a black background (Fig. 13.7).

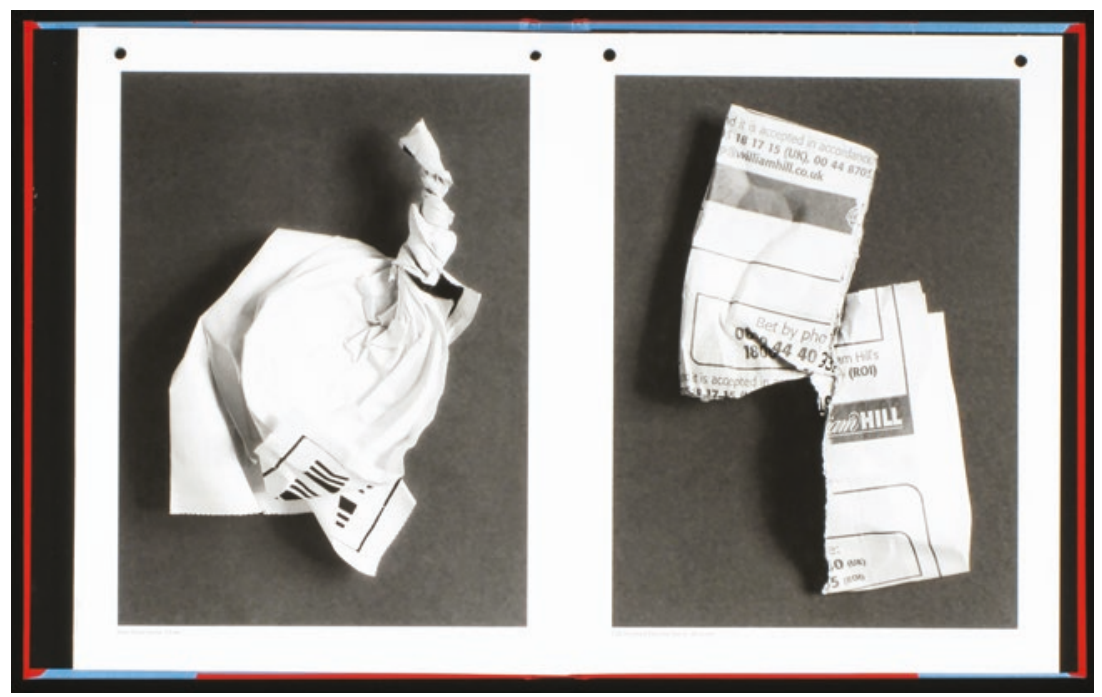

Fig. 13.7 From A Series of Disappointments (London 2008) by Stephen Gill, n.p. Copyright (C) 2008, Stephen Gill 
Watches, too, were advertised in this way, in black and white, as were jewels and other valuable products. Gill, however, has photographed discarded betting slips - that is, objects of no or of negative financial value, to be precise. The 36 slips were found in Hackney, a district of London that has three times as many betting shops as the rest of the city (see Miles 2010, 64). Although the lack of color and the two-sided positioning of the photographs have the effect that the objects are aligned more closely than in Stewart's photobook, they simultaneously possess a distinct individuality.

In the truest sense of the word: the two-dimensional slip becomes three-dimensional through the body of the bettor: "(N)ervous tension and grief" (Gill 2008) is what Gill called the emotions he sees as responsible for the fact that we do not see rectangular notes but rather types of death, crumpled up piles, torn, artfully turned or otherwise transformed pieces of paper that "began as hope, were shaped by loss or defeat, then cast aside" (Gill 2008). The failed bets are placed sparingly as text attached to the images (Fig. 13.8).

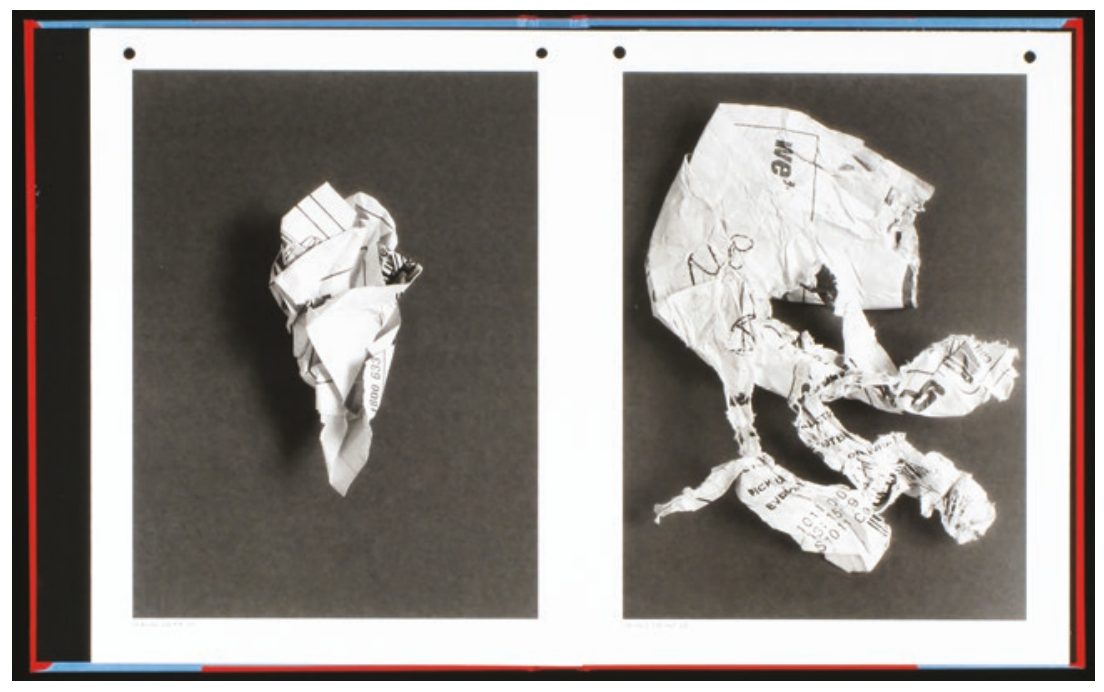

Fig. 13.8 From A Series of Disappointments (London 2008) by Stephen Gill, n.p. Copyright (C) 2008, Stephen Gill 
In addition to the act of leafing through, and printed as a fanfold, the book allows for a different mode of reception, which further differentiates the issue of value: owners of $A$ Series of Disappointments are encouraged to hang their own exhibition of the book. The book contains within it instructions for the removal of the text block from its cover and on how to properly hang the pages on small nails using the holes punched in the cover. The resulting long, continuous line, the "Series of Disappointments," underlines the extent of the loss and the repetition of frustration.

Melissa Miles stresses that this form of repetition is also typical for the CDp: "The repetition of photographs of a single, often banal subject has the effect of protracting and merging the photographed moments" (Miles 2010, 64-65). The disappointed hopes become one big disappointed hope, which is individualized by the formal difference of the betting slips. And yet the sheer amount of betting slips combined with the greatest standardization of the recording situation is a reductionist gesture that could be called a visual form of the list: the book is just an option for the display; the pages give the appearance of a showcase, an exhibition of living dead. There is no narrative, no dynamic owed to it. This visual list is neither complete nor discreet but produces surplus in the psychological charging of the form and received kinetic energy.

Formally, the betting slips have been transformed into signs-signs that refer to the structural change in Hackney and the poverty of the population as well as to the next page, which could possibly be showing the identical betting slip in a different form. This sculptural kind of aesthetic with its differentiated shades of gray borrowed from product photography, which in Walker Evans' and Karl Blossfeldt's work (Fig. 13.2) referred to the beauty of everyday life and pure form, is here called into question by a cultural product that-unlike Evans' pliers-has a negative rather than a low value. The simple listing emphasizes the loss of value, since the identical photographic treatment of the slips turns them into a singular mass, further stressing the huge loss of collective value. This practice is counteracted. The various deformations of the betting slips refer to the individuality of their owners. The kinetic energy, which is evident in the betting slips, highlights the extent of economic loss as well. It appears paradoxical how much money seems to be associated with a simple sheet of paper. Eventually, the book also draws our attention to the bizarre nature of banknotes, where value is again just a matter of agreement. As in Gill's series Billboards (2002-04), the fantasy worlds of advertising are visually provided with an ironic, yet highly political commentary. 


\section{Et Cetera Photobook}

In the following sections I would like to broaden my methodological focus and talk about cultural and literary approaches. This will allow me to work out the intermedial functions of the visual list more strongly and also to distinguish the enumerative qualities of the photobooks presented. So again: why do I use the term "et cetera photobook" in the title? I do not intend to define a new genre but rather to highlight a shared function of these books that the term Conceptual Documentary does not sufficiently emphasize. It is about the "and" and the "and so on," that is the connectors and the endings of enumerative systems. Peter Bexte has written several texts about the "and" and explored it not only as a verbal but also as a philosophical and visual phenomenon (see Bexte 2019).

Unlike analysis, the list is a form of synthesis. Like the word "and," it stands for connection as such, without its modality having yet been clarified. If one follows Bexte's argument, the list becomes a constructive phenomenon, a remedy against the crisis; the dissolution and the disintegration can at least be countered by a mere list. ${ }^{15}$ Lists turn against a causal logic. This can be linked to the CDp's claim that visual series are directed against humanist photography, which often works with dichotomies. As already emphasized by Melissa Miles, the CDp is also to be understood as a partial response to the crisis of representation in humanist photography. As a swan song to the pity-generating single image, it creates a series of images that, following no causal or chronological narrative, seems most likely to be associated with an "and." According to Bexte, the "and" (like the "or") is a disjoint conjunction, for it divides as it connects (see Bexte 2019, 21). $\mathrm{He}$ also emphasizes that conjunctions and prepositions have no meaning of their own in contrast to conceptual categories but that "their meaning always arises from the context" (Bexte 2019,51). This contextuality of the "and" is constitutive for the verbal and visual enumeration. Only in and with the context does the mode of enumeration open up; only then does it become clear whether one counts in an archival, typological, or hierarchical manner.

Due to the specificity of its medium, photography is particularly suitable for creating visual lists. The uniqueness of photographic textuality lies in the referential or indexical sign-like nature of the photographic image (see Hughes and Noble 2003,4). The indexicality of a photograph-its reference to a reality located in front of the image-creates a closer 
connection to the depicted than other media. Moreover, as Victor Burgin wrote in 1977, photographs_like language - are seen as part of the environment, "whereas paintings and films readily present themselves to critical attention as objects" (Burgin 1982, 143). The depicted can thus be more strongly present as a countable and delimitable sign, as evidenced by the numerous archival impulses in photo history (see Fig. 13.2), which can promote its list-likeness. It is also through this indexicality and through other characteristics such as the reproducibility, distributability, and cropping of a photograph that it is most context-sensitive, as photo theory argues. ${ }^{16}$ Abigail Solomon-Godeau points out that an evidential history of photography could therefore not be written without a "history of photographic uses" (Solomon-Godeau 1991, xxiv). And like the photo, the "and" is an "unsecured, because context-related meaning of connectors, brackets, couplings, etc." (see Bexte 2014, 32). Still, the "and" emphasizes a lack of hierarchy between the parts as a conjunction, which is most likely to remain invisible (see Bexte 2019, 15). This lack of hierarchy between the individual photos is also present in the CDp.

The contextualizing word produces repetitive loops, and yet it is important to emphasize that the "bidirectional directionality" (Selmani 2012, 171) of the "and" means that the law of exchange does not apply. As Bexte has shown, the words "father and son" have a different quality than "son and father" (see Bexte 2014, 31). Unlike in mathematics, neither literary, visual, nor semantic elements in general can be exchanged without consequences, a phenomenon already pointed out by Meyer Schapiro (see Meyer Schapiro 1969). In the examples shown here, for instance, the formal sequencing of Cases was needed to give coherence to the series, which otherwise had hardly any underlying ordering parameters. This coherence offers the basis for further considerations such as how the color orange is reflected in the work.

The "et cetera" can refer not only to the "and" but also to the "etc." and thus to the end of lists. The "et cetera" is then to be understood as a gathering, as an end that could go on. As already emphasized above, a bound book necessarily has an end, even if it appears as a fanfold. This seclusion is counteracted by the incomplete nature of the discrete individual elements: the "et cetera" is about the basic possibility of a subsequent rereading, a reassessment of what the agreement actually consisted of in the first place (see Garfinkel 1967, 74). 
The gaps and interstices are what I initially called the discursive power of the list. Therefore, Sabine Mainberger is to be agreed with when she states that enumeration-she deliberately avoids the word list-is "often marked as incomplete" but does not have to be "in principle infinite" (Mainberger 2018, 95-96). Thus, the photobooks dealt with here correspond to Mainberger's third category of infinity: "A finite number of items cannot be written down in full" (Mainberger 2018, 95-96). The "et cetera" is therefore not a sign of infinity but of detail. ${ }^{17}$

The CDp relies on the affordance of photography to freeze time, to isolate subjects from their surroundings, and to put them in a new context in which new associations and meanings can be forged. As the viewer has to recontextualize its isolated and thus abstracted objects, here the CDp shows itself in its openness and revisionality as well-behaved postdocumentary (see Gevers 2005). This postdocumentary quality is also evident in the sensitivity toward figural representation. Humanist photography has been criticized for, among other things, cementing injustices rather than helping to overcome them by representing unfortunate and needy people. People are not depicted in Stephen Gill's book, and hardly in Allison Stewart's and Ricardo Cases' books.

Of the examples shown here, the betting slips by Gill are most list-like in nature. The "and" between them can be understood as hung and leafed through; they are literally connected and, as such, are exhibited as a unit. This unity is further reinforced by the reduction of contexts already emphasized above: due to the many constant parameters, color, perspective, display, and background, the comparison is directed at the form of the betting slip and thus indirectly at the psychological condition of the owner-an owner who is not shown. This connects Gill's series to Stewart's backpacks: they both do not show the owners of the photographed objects. The color orange is an object-overlapping phenomenon for Cases as well. This representational void, together with the non-hierarchical order of the individual images, gives the viewer the opportunity to expand them imaginatively-both on the personal and on the political level.

This openness and revisionality are shared between visual and verbal enumerations. Literature is fascinated by lists because they seem to unite incompatible things very simply. Eva von Contzen emphasizes that lists in literary texts underline the constructiveness of the discourse, since they deflect classical reception expectations such as immersion: "Lists resist the immersive impetus and challenge readers on a cognitive level, requiring, to varying degrees, strategies of familiarization and narrativization in order 
to make sense of their meaning" (von Contzen 2016, 246). This refusal of immersion-or of narrative-is also inherent in the examples that I have presented in this article.

\section{Horizons of RecEPTION}

Christiane Frey and David Martyn begin their essay on knowledge in and through lists with a remark on reception aesthetics: we would read "over the individual elements of a list" (see Frey and Martyn 2016,91) if we knew the heading, the category under which the elements would be subsumed. The authors speak of horizons of expectation with which the reader is equipped. If we ask ourselves when and who is equipped with which horizons of expectation, then we have a clear winner: Bug out Bag is too well known as a term and too ubiquitously understood than to have to guess for a long time what kind of unpacked backpacks might be depicted. But neither Cases nor Gill allows such simple conclusions to be drawn from the title of the work on display: the fact that the color orange could become the smallest common denominator within Cases' enumerative structure is something the viewer, despite the title, only realizes after turning the pages several times; no text is assigned to the pictures that could guide the viewer in Gill's work to associate the disappointment mentioned in the title with the betting-slip sculptures. Even if " 3.20 Hereford Earcome Sannie $£ 5$ to win" provides only very fragmentary information about the betting context, it is the combination of visible fonts in the image and the captions that slowly makes the viewer aware of the fact that they are seeing betting slips. It is also the suggestive materiality of the book (the way in which it reminds us of the black-and-white photography as is typical for jewelry catalogues) that meaningfully leads the viewer astray. If the category or/and a certain hierarchy is given in advance, the following would no longer be a "mere" list but a catalogue, that is, a "hierarchical subsumption of particulars under general terms" (Frey and Martyn 2016, 96). This differentiation can also be applied to visual forms of cataloguing. What works as a list when, how, under which conditions, and in which media also depends on the viewer's stance. The list is an associative principle that exists primarily in a cognitive capacity as "object and process" (Bronfen et al. 2016, 8). However, if a list is a cognitive tool, as Eva von Contzen emphasizes (see Frey and Martyn 2016,96), we have to ask how the concept of a visual list comes about. In the beginning, I put 
forward the thesis that it is a reductionist and abstracting act that aligns the polysemic image to the disjointed sign. Abstraction occurs through countable repetition and formal reduction, a principle that the CDp has adopted from serial art. The reduction is achieved amongst others by equalizing the shooting parameters that the photographer imposes on his series, which is often accompanied by a high degree of staging.

\section{CONCLUSION}

A cluster is not a list because the elements are not discrete but overlap. Visual lists therefore rely on conjunctions, the "and" must be exposed to show the enumerative quality of the image. This can be realized in various ways. In my examples it is the page and the associated page turning as a visual blink that creates that structure. Even though lists can do both, separate and connect, they are more visible when they separate. But to what extent does the list then strive for its own erasure and to what extent does it expose itself?

Sabine Mainberger suggested that enumerative texts either "accentuate the diversity of the individual elements" and as a result appear 'objective' and 'factual" or emphasize "the equalizing" and "repetitive," which makes them appear "ritualistic' and 'obsessive" (Mainberger 2003, 95). It is not quite that simple with visual enumerations: Ricardo Cases' photographs attach less importance to repetition than to difference, yet on the pictorial level it is primarily the exaggerated colorfulness and the access to objects, which oscillates between surreal and expressive, that contradicts attributions such as "objective" or "factual." However, the thesis seems to apply to Stewart's photobook. Her prepper-hauls emphasize diversity and create order at the same time. The individual objects gain meaning through their connection to the other objects and through their relationship to the whole of the bag. Stephen Gill's enumerations seem most repetitive, but not obsessive. Yet, one of his aims is certainly to represent the mass of betting tickets in Hackney. Creating a list is always an act of abstraction. When a list is created, the individual items become both reduced and more complex: reduced because they are cut off from previous (semantic) contexts, and more complex because they are entangled in new semantic structures within the list.

Martin Parr has described humanist photography as much too preachy (see Miles 2010, 57). Lists cannot preach. The CDp abstracts/reduces its theme to a list in order to allow further (crisis) description. As a serial work, the visual list can be both politically and conceptually coherent. Gill 
and Stewart use the camera's dyadic power to isolate its object and remove it from its social context in order to generate a much more open conceptual economy for Contemporary Documentary photography.

Following my initial thesis, various ways in which signs emerge can be distinguished in the photobooks: the enumerative character is less obvious in Cases, as he does not singularize his objects like Gill or Stewart. Nevertheless, one looks for the color orange. By the time you find it, you have seen a lot of the once rich but now disused region around Valencia and have experienced the way in which light is able to illuminate the worn, peeled, and dried up plains. Through the back door of a narrative that deflects to be subsumed, Cases is thus able to draw attention to the forgotten contexts of the region. Stewart's glass cabinet backpacks, on the other hand, are most closely based on the photographic tradition of the inventory-an isolated, future inventory that receives its sign-like aspects from the absence of the owners. Every canned tuna, every battery thus refers to someone who is only present as a first name in the book. Stephen Gill's photobook A Series of Disappointments is best described as a visual list, while with regard to Stewart and Cases it seems more appropriate to speak of enumerations or enumerative systems, for in addition to the necessary reduction involved to create a discrete sign, Gill's work also adjusts another parameter: that of space.

If you turn the pages of Cases' book, the place where the photo was taken changes on every page. Sure, we are always in the same Spanish region, but in very different places, where the viewer is confronted with very different things. This changes with Stewart: here, the place seems to be the same, and yet the viewer is aware that Stewart had different backpacks unpacked at different places, in which she found different things. This distinction also disappears in Gill's series: you always see the same thing in the same place. Because the recording situation is unchanged, the viewer can respond more quickly to the depicted objects and their similarities and differences. The betting slips are arranged differently, but they always remain betting slips that he has picked out and photographed in black and white on a neutral surface. The fanfold, which makes it possible to display the pages as a row or as a line, also refers to a spatial continuity - and thus to a further alignment with the writing. Similarly, Gill's camera is the only one that is static, while Stewart changes the distance of the camera to her objects to visually match stuffed and not so stuffed pockets.

I began this text by arguing that lists create surplus. Visual enumerations in the documentary photobook also create this surplus: disappointed 
hopes with Stephen Gill, dystopian fears with Allison Stewart, and tourists' desires with Ricardo Cases. Strictly speaking, this surplus is not visually represented in their books, but it is still present. A semantic and an affective surplus, an emotional level of perception that is generated for and ultimately also by the recipients themselves. The CDp makes use of the apparently non-hierarchical and unfinished structure of enumeration in order to counter the hierarchical problem of humanist photography. Additionally, it emphasizes the interpretive gaps between individual images and thus creates a receptive autonomy, which is also an important representational goal in other approaches to Postdocumentary Art. It uses the decontextualization of space, time, and presence to emphasize the photo as a sign and to counter the crisis through a series of signs, the first step of which can be an "et cetera," a list.

\section{Notes}

1. I will use the acronym CDp for the term in the following.

2. Andrew Piper describes this process: "They convey a sense of the development of readerly thought" $(2012,52-53)$.

3. For research on diagrammatics see also Schmidt-Burkhardt (2012).

4. Distance refers to an act of reception: as soon as the viewer compares a work with other works, it no longer stands on its own but at the same time also exemplifies the aesthetic set of rules that justifies its inclusion in the overarching system of presentation. See Thürlemann $(2013,16)$.

5. The list as a means of expressing excess can also be found in literature. Monika Fludernik quotes a passage from Oliver Twist, in which the protagonist's sensory overload in a market is communicated via an excessive description. See Fludernik (2016).

6. I am referring here to criticism of Western Documentary or humanist photography, which, by portraying the "non-Western" as deplorable and in need of help, consolidated rather than helped to overcome this asynchronicity. See Solomon-Godeau (2003).

7. Cornell Capa, the brother of Robert Capa and director of the International Center of Photography in New York, defines the approach of the concerned photographer as follows: "The concerned photographer finds much in the present unacceptable which he tries to alter" (Cookman 2009, 130). Capa was also the one who established the expression "concerned photographer" for his photographs, because the images should have a humanitarian impulse. There are two anthologies titled The Concerned Photographer, published by him in 1968 and 1972, which define the genre. See Capa (1968) and (1972). 
8. Fox Talbot (1844).

9. Blossfeldt (1928). Blossfeldt was not a photographer by profession but a sculptor. His photographs were taken in the 1890s as illustrations for the art educational writings of his first employer, Moritz Meurer, and later as models for his own lessons in "modelling from living plants" at the Unterrichtsanstalt des Kunstgewerbemuseums Berlin, where Blossfeldt taught from 1899 to 1930.

10. See Ruscha (1964). Additionally, Walker Evans should not go unmentioned here. His work Beauties of the Common Tool was published in July 1955 in the magazine Fortune, which he also edited as picture editor. Even here, in the contextless formal aesthetics of pliers, scissors, and spatulas, a profanation of Blossfeldt's approach can be observed. See Campany (2014).

11. For Ruscha, photography is not "arty" and is already dead as an art form. In an interview about his books he said in 1964: "Thus, it is not a book to house a collection of art photographs - they are technical data like industrial photography. To me, they are nothing more than snapshots" (quoted after van der Weijde 2017, 125).

12. Herein as well as in terms of the diversity of the thematic framework, the book recalls Ed Ruscha's Various small Fires and Milk (1964).

13. Although he works with color, this aspect is most closely related to the tradition of Ed Ruscha, who also depicts fires in his photobook Various Small Fires and Milk (1964).

14. See Scheuermann $(2010,203)$. David Herman considers the question how the viewer is guided to narrative conclusions as an important element of postclassical narratology: see Herman (1997, 1057).

15. When considering the list as a form of montage, a remark by Bernd Stiegler might prove enlightening here, who observes montages particularly in situations of upheaval. Such situations give rise to new cultural forms; these forms, however, need not be homogeneous and can retain their heterogeneity. See Stiegler $(2009,310)$.

16. See Solomon-Godeau (1991, xxiv).

17. Umberto Eco had already pointed this out when he said that the painting The Ten Thousand Martyrs by Jacopo da Pontormo did not have to depict 10,000 people to do justice to this title. See Eco $(2009,39)$.

\section{REFERENCES}

Armstrong, Carol M. 1998. Scenes in a Library: Reading the Photograph in the Book, 1843-1875. Cambridge, MA: MIT Press.

Bexte, Peter. 2014. ,und': Bruchstellen im Synthetischen. In Synthesis - Zur Konjunktur eines philosophischen Begriffs in Wissenschaft und Technik, ed. Gabriele Gramelsberger, Werner Kogge, and Peter Bexte, 25-40. Bielefeld: 
transcript. https://www.degruyter.com/document/doi/10.14361/transcript.9783839422397.25/html

- 2019. Konjunktur \& Krise: Vom ,und' in Bildern und Texten. Berlin: Kadmos.

Blossfeldt, Karl. 1928. Urformen der Kunst. Berlin: Verlag Ernst Wasmuth. Rijksmuseum Amsterdam. http://creativecommons.org/publicdomain/zero/ 1.0 .

Bochner, Mel. 1967. The Serial Attitude. Artforum 6 (4): 28-33.

Bronfen, Elisabeth, Christiane Frey, and David Martyn. 2016. Vorwort. In Noch einmal anders: $Z u$ einer Poetik des Seriellen, ed. Elisabeth Bronfen, Christiane Frey, and David Martyn, 7-16. Zürich/Berlin: diaphanes.

Burgin, Victor. 1982. Looking at Photographs. In Thinking Photography, ed. Victor Burgin, 142-153. London: Macmillan.

Campany, David. 2014. Walker Evans: The Magazine Work. Göttingen: Steidl. Capa, Cornell. 1968. The Concerned Photographer. New York: Grossman.

. 1972. The Concerned Photographer 2. New York: Grossman.

Cookman, Claude Hubert. 2009. American Photojournalism: Motivations and Meanings. Evanstone: Northwestern University Press.

Dobbe, Martina. 2013. Einsheit und Vielheit: Zur Bildökonomie des Seriellen. In BildÖkonomie: Haushalten mit Sichtbarkeiten, ed. Emmanuel Alloa and Francesca Falk, 29-53. Munich: Wilhelm Fink Verlag.

Dunker, Bettina. 2018. Bilder-Plural: Multiple Bildformen in der Fotografie der Gegenwart. Paderborn: Wilhelm Fink Verlag.

Eco, Umberto. 2009. Die unendliche Liste. Trans. Barbara Kleiner. Munich: Hanser. Eskildsen, Ute. 2004. Photographs in Books. In The Open Book: A History of the Photographic Book from 1878 to the Present, ed. Andrew Roth, 11-29. Göteborg: Hasselblad Center.

Fludernik, Monika. 2016. Descriptive Lists and List Descriptions. Style 50 (3): 309-326. https://doi.org/10.5325/style.50.3.0309.

Frey, Christiane, and David Martyn. 2016. Listenwissen. Zu einer Poetik des Seriellen. In Noch einmal anders: $Z u$ einer Poetik des Seriellen, ed. Elisabeth Bronfen, Christiane Frey, and David Martyn, 89-103. Zürich/Berlin: diaphanes.

Garfinkel, Harold. 1967. Studies in Ethnomethodology. Englewood Cliffs: Wiley.

Gevers, Ine. 2005. Images that Demand Consummation: Postdocumentary Photography, Art and Ethics. In Documentary Now! ed. Frits Gierstberg et al., 82-99. Rotterdam: NAi Publishers.

Gill, Stephen. 2008. Description in the Webshop. https://www.nobodybooks. com/product/a-series-of-disappointments-blue-red. Accessed 15 May 2020.

Herman, David. 1997. Scripts, Sequences, and Stories: Elements of a Postclassical Narratology. PMLA 112: 1046-1059. 
Hughes, Alex, and Andrea Noble. 2003. Introduction. In Phototextualities. Intersections of Photography and Narrative, ed. Alex Hughes and Andrea Noble, 1-16. Albuquerque: University of New Mexico Press.

Mainberger, Sabine. 2003. Die Kunst des Aufzäblens: Elemente zu einer Poetik des Enumerativen. Berlin/New York: de Gruyter.

- 2018. 2.9 Ordnen - Aufzählen. In Handbuch Literatur \& Materielle Kultur, ed. Susanne Scholz and Ulrike Vedder, 91-98. Berlin/Boston: de Gruyter.

Miles, Melissa. 2010. The Drive to Archive: Conceptual Documentary Photobook Design. Photographies 3 (1): 49-68. https://doi.org/10.1080/ 17540760903561108/.

Molderings, Herbert. 1977. Überlegungen zur Fotografie der Neuen Sachlichkeit und des Bauhauses. kritische berichte 5 (2/3): 67-88.

Nelson, Andrea Jeannette. 2007. Reading Photobooks: Narrative Montage and the Construction of Modern Visual Literacy. PhD dissertation, University of Minnesota.

Pantall, Colin. 2014. The Reason of Oranges. British Journal of Photography Online, September 23. https://www.bjp-online.com/2014/09/the-reasonof-oranges. Accessed 26 June 2020.

Piper, Andrew. 2012. Book Was There. Reading in Electronic Times. Chicago: University of Chicago Press.

Ruscha, ed. 1964. Various Small Fires and Milk. Anderson, Richie \& Simon: Los Angeles.

Schapiro, Meyer. 1969. On Some Problems in the Semiotics of Visual Art: Field and Vehicle in Image-Signs. Semiotica I: 223-243.

Scheuermann, Barbara J. 2010. Narreme, Unbestimmtheitsstellen, Stimuli Erzählen im fotografischen Einzelbild. In Die fotografische Wirklichkeit: Inszenierung - Fiktion - Narration, ed. Lars Blunck, 191-205. Bielefeld: transcript.

Schmidt-Burkhardt, Astrit. 2012. Die Kunst der Diagrammatik: Perspektiven eines neuen bildwissenschaftlichen Paradigmas. Bielefeld: transcript.

Scott, Clive. 1999. The Spoken Image: Photography \& Language. London: Reaktion Books.

Selmani, Lirim. 2012. Durch 'und' hervorgerufene mentale Prozesse. Deutsche Sprache: Zeitschrift für Theorie, Praxis, Dokumentation 2: 166-185.

Solomon-Godeau, Abigail. 1991. Photography at the Dock: Essays on Photographic History, Institution, and Practices. Minneapolis: University of Minnesota Press.

- 2003. Wer spricht so? Einige Fragen zur Dokumentarfotografie. In Diskurse der Fotografie: Fotokritik am Ende des fotografischen Zeitalters, ed. Herta Wolf, 53-74. Frankfurt/Main: Suhrkamp.

Stiegler, Bernd. 2009. Montagen des Realen: Photographie als Reflexionsmedium und Kulturtechnik. Munich: Wilhelm Fink Verlag. 
Sweetman, Alex. 1985. Photobookworks: The Critical Realist Tradition. In Artists' Books: A Critical Anthology and Sourcebook, ed. Joan Lyons, 187-207. Rochester: The Visual Studies Workshop Press.

Talbot, William Henry Fox. 1844. The Pencil of Nature. Plate III: Articles of China. http://www.fotomanifeste.de/user/pages/manifeste/1844-TalbotPencilOfNature/faksimile-talbot.pdf?g-bd986df0. Accessed 23 June 2020.

Thürlemann, Felix. 2013. Mehr als ein Bild. Für eine Kunstgeschichte des hyperimage'. Munich: Wilhelm Fink Verlag.

van der Weijde, Erik. 2017. This Is Not My Book. Leipzig: Spector.

von Contzen, Eva. 2016. The Limits of Narration: Lists and Literary History. Style 50 (3): 241-260. https://doi.org/10.5325/style.50.3.0241.

Weltzien, Friedrich. 2006. Die Bildtechnik der Höflichkeit. William Henry Fox Talbots kontrollierte Affekte. In Fotografische Leidenschaften, ed. Katharina Sykora et al., 19-32. Marburg: Jonas Verlag.

Wolf, Werner. 2002. Das Problem der Narrativität in Literatur, bildender Kunst und Musik: Ein Beitrag zu einer intermedialen Erzähltheorie. In Erzäbltheorie transgenerisch, intermedial, interdisziplinär, ed. Ansgar Nünning and Vera Nünning, 23-103. Trier: WVT.

Open Access This chapter is licensed under the terms of the Creative Commons Attribution 4.0 International License (http://creativecommons.org/licenses/ by $/ 4.0 /$ ), which permits use, sharing, adaptation, distribution and reproduction in any medium or format, as long as you give appropriate credit to the original author(s) and the source, provide a link to the Creative Commons licence and indicate if changes were made.

The images or other third party material in this chapter are included in the chapter's Creative Commons licence, unless indicated otherwise in a credit line to the material. If material is not included in the chapter's Creative Commons licence and your intended use is not permitted by statutory regulation or exceeds the permitted use, you will need to obtain permission directly from the copyright holder.

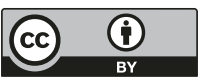

